\title{
THE PROPOSED UNIFORM MECHANICS' LIEN LAW *
}

\section{EDIard H. Cushman $†$}

If Sir Thomas More had been a builder, perhaps his Utopia would have depicted the ideal commonwealth as a place where owners dealt only with qualified contractors, paid these contractors monthly eighty-five per cent. of the value of the labor and material furnished to the sitc, and sixty days after the substantial completion of the building, punctually paid the full retained percentage. These contractors in turn dealt only with responsible subcontractors and materialmen. All labor was skilled, all work was performed in a good and workmanlike manner, all material conformed to specifications, and contractors and subcontractors discounted their bills. Here there would be no need for either lien laws or bond legislation, and certain lawyers, instead of specializing in building construction problems, would find it necessary to look for new worlds to conquer. Unfortunately a far different condition has always confronted the building construction industry.

Analogies to the right of mechanics' liens are not wanting, even in the ancient Roman law. The right of lien in its inception was recognized in the Twelve Tables, and by a constitution of the Emperor Marcus Aurelius, it was provided that one who loaned money for the restoration of an edifice, but not for the erection of a wholly new building, had a right of hypotheca on the edifice and on the ground on which it stood, provided that the money was loaned expressly for the restoration of such buiiding. ${ }^{1}$

In France by the Code Napoleon, masons, architects, contractors and others employed in building houses were accorded liens."

The first of such laws in America was enacted as a result of the desire to facilitate the construction of buildings in the proposed capitol City of Washington. In I $79 \mathrm{I}$, at a meeting of the commissioners appointed for such purpose, both Thomas Jefferson and James Madison being present, a memorial was adopted urging the General Assembly of Maryland to pass an act securing to master builders the right of lien. The requested law was enacted December I9, I79I. ${ }^{3}$

*This article is based, in part, on an address delivered by the writer before the Convention of the Associated General Contractors in Mrilwaukee on Jan. 20, 1932.

iLL. B., Temple University, Igzo. Author Law of Mrecharics' Liens in Pexissyzvanta, Boxiss ox Püblic Iarprovexrents, and of a number of brochures pertaining to laws and legislation in connection with the building construction industry.

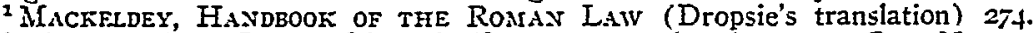

II Dosist, Civtl LAw (IS6I ed.) 68I-4, arts. 1736 and I74I-5; CODE NAPOLEON, privileges and mortgages, section 2, article 2103; Moore-Mansfield Constr. Co. v. Indianapolis, itc. R. R. I79 Ind. 356, 369, Ior N. E. 296, 301 (1913).

${ }^{3}$ Laws of Maryland, Chap. $45, \S$ Io.

The first Pennsylvania statute authorizing a mechanic's lien for labor furnished in and about the erection and construction of a building was the Act of April r, r803, P. L. 79 r. 
The various types of statutes may be divided into three classes. One is known as the New York system, under which the lien of a subcontractor or materialman depends upon and is limited to the money due from the owner to the contractor at the time of the filing of the notice of lien and to such moneys as may become due to the contractor between the time of filing the notice and the trial of the action to foreclose the lien. ${ }^{*}$

The second type consists of legislation whereby the owner is not held liable for more than the contract price, but there is imposed upon hin, while making payments, the duty of requiring from the contractor a statement under oath, showing sums due or to become due to subcontractors and others. The owner is required to retain such part of the money due the contractor as may be sufficient to meet the obligations shown by the contractor's statements, as well as moneys claimed to be due by subcontractors and others.

The third type is that which is known as the Pennsylvania system, under which the right of the subcontractor to a lien does not depend at all upon the existence of any indebtedness of the owner to the subcontractor. The theory of such a law is that the persons adding to the value of the owner's estate are entitled to the security of a lien, unless the latter has protected himself by a contract against liens as authorized by the statute. It is implied in the law that the contractor may secure the aid of competent persons, and the necessary material to construct the building, at the charge of the owner. The underlying theory of such mechanics' lien legislation is that it is equitable that he who furnishes material or labor in the construction of a building for the benefit of the owner should be made secure against the property on which the structure was erected and this equitable doctrine runs in favor of a subcontractor as well as the contractor. ${ }^{5}$

This act was confined to the City of Philadelphia, the District of Southwark and the Township of Northern Liberties. By reason of the novelty of the subject it happened that the first act fell short of its object in omitting to secure subcontractors. Additional legislation followed and the body of laws relating to mechanics' liens grew up through many years by yradual additions without regular order or preparation. In IgOI it was deemed advisable to revise this fragmentary legislation by a comprehensive, consistent act better adapted to present conditions and more complete in its scope and objects. The meritorious of the then existing statutes were incorporated in the Mechanics' Lien Act of June 4, I90I, P. I. 43I, with such additions as experience had shown to be desirable. This act has been praised as an example of lucidity in the art of legislative expression deserving of high commendation, but certain of its provisions have been held to be unconstitutional because the same are divergent from and an advance upon the law as it stood at the time of the adoption of the Pennsylvania Constitution of 1874 . Section 7. Article III of the Constitution of 1874 provides that "the General Assembly shall not pass any local or special law authorizing the . . extension . . of liens". Thereiore, it has been held that the provisions of the Mechanics' Lien Act of I 001 and its supplements which conier upon mechanics' lien claimants rights which they did not possess in $88+4$ are unconstitutional. Of course, the legislature may restrict the rights possessed by mechanics lien claimants in 1874 , as, for example, the requirements making notice of intention to file a mechanic's lien a prerequisite to the right of a subcontractor to maintain such a claim. Heist $v$. Mnntayne, 53 Pa. Super. 6r t. (I6 (IoI3).

It may well be argued that Article 111 , Section - of the F'emsivivania Constitution of 1874 was never intended to apply to mechanics' lien legislation, but it is reasonable to assume ti:at the Supreme Court of Pennsylvania will not at this late stage reverse itself. The best that can be hoped for is that it will not extend the application of this section.

- $\mathrm{A}$. I. Coxs. Law' (1900) c. 33. as amended by X. Y. Laws 1930, 1591 .

- Eryan v. Stempkowski, 88 Pa. Super. 390 (1926). 
The proposed Uniform Act follows, in the main, the second type above described but suggests a number of changes. ${ }^{6}$

The Uniform Act recognizes two principal classes of cases in which those furnishing material, labor or services may be protected under lien laws. In the first, the owner is solvent but the contractor fails to pay laborers, subcontractors or materialmen on time. The second arises where the owner is unable or fails to carry out his payment to the contractor. ${ }^{7}$

The proposed act fails to place due emphasis on the situation which arises where the contractor fails to pay subcontractors and materialmen. As an abstract proposition, the contention may properly be made that subcontractors and materialmen should look for payment primarily to the person to whom they extend credit. As a practical matter, it is important to owners and to responsible general contractors that the lien law should extend adequate protection to subcontractors and materialmen. The right of lien must be one which responsible subcontractors or materialmen will use. It does not follow that if responsible subcontractors refrain from bidding the contractor will be unable to proceed with the work. We have learned by sad experience that there will always be irresponsible constructors or ambitious novices who will take a job for less than the fair value of the labor and material required to be furnished and then by either supplying inferior material or skimping the work, or both, seek to come out whole. Hence, the owner who selects a cheap contractor, frequently finds that the subcontractors were on a par with the general contractor and that the building which he obtained is not the building which he had expected to own.

The argument that the person supplying labor or material should look for payment primarily to the person with whom he contracted can be applied to the general contractor in his dealings with the owner. It is no more applicable here than in the case of subcontractors.

The Hon. Owen J. Roberts in a speech before the Philadelphia Builders' Exchange, delivered on February I, I9I7, sets forth the following clear reasoning:

"It is argued by some persons that a lien is a special privilege and that there is no reason why a special privilege should be extended to people who sell materials which go into buildings as compared with people who sell any other lind of commodity. The answer which peo-

'A committee appointed by Mr. Hoover, when Secretary of Commerce, in Ig25, to consider the necessity of a uniform mechanics' lien act and to prepare such an act if desirable, has reached an agreement upon a draft, copies of which may be obtained irom the Bureau oi Standards, Department of Commerce, IVashington, D. C. This committee has co-operated with the National Conference of Commissioners on Lniform State Laws. The Lniform Mechanics' Lien Act which has been considered by the Xational Conference since 1926 has been tentatively adopted and will receive consideration at the 1932 conference to be held at Vashington in October. See Proceedings (I93I) 56 A. B. A. Rep. 4 I.

'See first tentative draft of a uniform mechanics' lien act prepared by the Standard State Mechanics' Lien Act Committee of the Department of Commerce, Washington, I926, p. 8. 
ple in the building trades make to this criticism is that it is not possible for a subcontractor or material man to spread his risk in the same way that the ordinary merchant does. In the building trade enormous quantities of material and labor go into a single operation and that operation may require labor and material over a period of say, six months. A subcontractor or material man cannot take contracts on many operations and it results that his whole capital is tied up in some three or four, or possibly, a dozen operations. If the general contractor on any of these operations goes bad, the risk that he will pull down with him some of the subcontractors and material men is very great. The business is in this respect different from other lines of business and it is not an unfair discrimination to grant certain protection to persons engaged in this line which is not practicable to grant to the general merchant."

If the lien laws are so written that responsible subcontractors and materialmen are sure of a reasonable amount of protection, the owner will receive better work.

Under the Pennsylvania system, an owner who selects a cheap contractor and fails to file a waiver of liens of record may be required to pay more than the original contract price by reason of mechanics' liens which are filed against the premises. ${ }^{8}$ Under the New York system the owner, generally speaking, cannot be compelled to pay to lien creditors, for the work of construction, more than the contract price.

\section{Premature Notice Defeats Purpose of Legislation}

The proposed Uniform Mechanics' Lien Act is not fair to subcontractors and materialmen and is, therefore, unjust to responsible general contractors.

This Act requires every person, except laborers and persons who contract directly with the owner, at any time before beginning work, but not later than thirty days after beginning and not later than the day of completion of his work, to give the owner a written notice of intention to claim a lien. ${ }^{9}$ This requirement will, in many cases, render the lien law a meaningless nullity and thus, in a measure, defeat the purpose of the legislation.

A number of states, including Pennsylvania, require notice of intention to claim a lien. ${ }^{10}$ The writer has made inquiry from niaterialmen and

\footnotetext{
${ }^{8}$ The contractor may, by a waiver of liens, duly filed and indexed, bar claims by subcontractors. Mechanics' Lien Act of I90I, P. L. 43I, §I5, PA. STAT. ANN. (Purdon, 1930) title $49, \S 72$, amended by the Act of April 24, I903, P. I. 397, § I. Bennar v. Central Mausoleum, $304 \mathrm{~Pa} .569$, I56 Atl. 239 (193I).

The Uniform Mechanics' Lien Act is much more equitable to the subcontractors and others, since it provides "any person other than a laborer may, as a part of his contract, waive in writing his lien under this act, but a laborer may not waive his lien" ( $\$ 27)$.

'Proposed Uniform Mechanics' Lien Act (hereinafter abbreviated in footnotes as U. $M$. L. A.) $\$ 4$

${ }^{20}$ From tables prepared in 1930 , the following data is available:

Time when notice is required: before furnishing any labor or material, New Hampshire; before any labor or material is furnished, where the building contract and specifications are
} 
others in a number of states where notice is required at an early stage of the work, and, in every instance, has been informed that subcontractors and materialmen, in the majority of cases where early notice is required, prefer to lose their rights of lien rather than to offend contractors with whom they are doing business.

Naturally, if such notice becomes known to the owner, the owner construes it as a reflection upon the financial condition of the contractor and the embarrassing situation which frequently follows is blamed by the contractor on the subcontractor, who merely complied with the statutory provision.

In Pennsylvania, a distinction is made between new work and alterations and repairs. In the case of altarations or repairs an informal preliminary notice is required on or before the date the claimant furnishes the last of his labor or material, ${ }^{11}$ and a formal notice within forty-five days thereafter. ${ }^{12}$ Thus, when subcontractors choose not to give notice and fail to collect from the contractor, their losses are slight because the average alteration job does not involve a substantial amount of money. A substantial alteration effecting a change in the exterior of a building is treated as a new building and such preliminary notice is not required. ${ }^{13}$ In the case of new work or such a substantial alteration, the subcontractor is not required to give any notice until three months after he has furnished the last of his labor and material. This is a reasonable time and hence it is not necessary for a subcontractor to suffer the loss of all or part of his profits-if anyby retaining counsel until the contractor had at least sixty days to pay the subcontractors.

It might be argued that the form of notice required by the proposed Uniform Act is so simple that a layman can prepare it. This is true, yet the Pennsylvania Mechanics' Lien Law was designed to provide a simple remedy which would permit a layman to be his own lawyer. The result in Pennsylvania has been that, when a layman so acts, he usually has a fool for a client.

not recorded (they usually are recorded), New Jersey; 5 days after first delivery of material, Washington; 15 days aiter first delivery of material, Michigan; 30 days after first labor and material, IVisconsin; 6o days after furnishing labor and material, Connecticut; Jaryland, Rhode Island, IVest Virginia; within 4 months after labor or material is furnished, Oltio; 30 days after completion of building, Virginia; 90 days after completion of building, Tennessee; go days after debt accrues, Texas.

In Arkansas, MLaryland and $V$ yoming, the notice must be given a stipulated number of days before a mechanic's lien claim is filed. In Colorado, Florida, Massachulsetts, Mississippi, North Carolina, South Carolina, South Dakota and Vermont, no specific time is fixed, but the lien is restricted to the unpaid portion of the contract price not required for the purpose of completion remaining in the hands of the owner after notice is given.

"Mechanics' Lien Act of Igor, supra note $8, \$ 2$.

In Ibid. \$ 8, as amended by the Act of March 24, Ig09, P. L. 65, PA. Stat. Axv. (Purdon, I930), title $49, \S$ IOI.

${ }^{23}$ Eisenberg v. Wolf, $86 \mathrm{~Pa}$. Super. I69 (I925). 


\section{Time for Filing Liens Too Short}

Under the proposed Uniform Act, the claim of lien may be filed at any time during the progress of the work, but not later than three months after the final performance of labor or services by the lienor. ${ }^{14}$

An ideal credit situation would be one in which payments were made within sixty or ninety days after the labor or material was furnished. However, contractors frequently feel that the architect or engineer has reduced the monthly payment claimed by the contractor in his requisition to a sum less than the amount which the owner should be required to pay the contractor as the work progresses. The owner who pays the retained percentage within sixty or ninety days after completion of the building is an exceptional individual, and the contractor who pays his bills within ninety days is likewise an exception to the general rule.

The proposed Uniform Act forces the subcontractor and materialman to elect to exercise his right of lien at a time prior to the time when an owner usually pays the contractor. It is unreasonable to expect the contractor to pay subcontractors in full before he has received payment from the owner. The contention that credit practices can be reformed by legislation is untenable.

In Pennsylvania a lien for alterations and repairs must be filed within three months after the claimant has furnished his last labor and material, ${ }^{15}$ but in the case of new work the claimant has six months within which to file his lien. ${ }^{16}$ The Pennsylvania statute affords subcontractors a sufficient opportunity, having regard to actual conditions as they exist in the building industry, to make every reasonable effort to collect from the contractor before being forced to retain counsel.

In New Jersey ${ }^{17}$ and for private work in New York, $^{35}$ claimants have four months within which to file their lien. Apparently these provisions have not worked a hardship on responsible contractors or on the owners. The time for filing lien claims varies considerably in the different states. ${ }^{19}$

"U. M. L. A. \$17. It has been urged that the right to file a mechanic's lien during the progress of the work may seriously affect the ability of the contractor to proceed with the work. However, as a practical matter, a claimant rarely, if ever, files a lien prior to the completion of his contract or the suspension of his work, since the average business man would prefer to exhaust all other means of settlement beiore resorting to the expense, delay and inconvenience of litigation.

${ }^{25}$ Mechanics' Lien Act of 1901, supra note 8, § Io.

${ }^{10}$ Ibid.

${ }^{27}$ N. J. Laws I898, p. $538, \S 16$, N. J. CoNp. Stat. (I9I0) p. 3303; Treeland Co. v. Knickerbacker, 75 A. J. L. 551, 68 Atl. 215 (I907).

${ }^{18}$ N. Y. Coxs. Laws, supra note $4, \S$ ro.

${ }^{19}$ In Alabama (by journeymen), California (by subcontractors), Colorado (by laborers), Massachusetts and Oregon (by subcontractors), lien claims must be filed within 30 days after the labor or material has been furnished.

In Alabama (by contractor), Kentucky, Maryland and Missouri (by contractor), North Carolina and Pennsylvania (for new work), the lien claims must be filed within 6 months after the claimant has furnished the last of his labor or material.

In Mississippi, the claim must be filed within one year after the claimant has furnished the last of his material.

In the other states, the time for filing claims varies between these extremes. 
The contention would unquestionably be made that a modification postponing the time within which notice must be given and extending the time for filing a lien claim is unfair to the owners. Let us examine this contention. Under the Pennsylvania system, by which subcontractors, if they have the right of lien, can recover the reasonable value of the labor and material furnished irrespective of the amount due the contractor by the owner, unquestionably an owner might be subjected to the liability of double payment, $i$.e., payment first to the contractor and subsequently to the claimant who filed a valid lien. 20

Under the proposed Uniform Act, however, this liability of double payment disappears because lien claimants, other than laborers, may recover only the balance of the contract price fixed by the contract of the contractor or subcontractor. ${ }^{21}$ Thus, the owner who has complied with the provisions of the lien act cannot be required to pay the same debt twice. The only inconvenience to the owner, therefore, is his inability to finence the property during the lien period unless satisfactory releases of liens are obtained or other assurances given the lender that the mortgage will be a prior lien. Likewise, if the owner desires to sell the building within the statutory period for filing liens, the owner must give the purchaser satisfactory assurance that the conveyance is clear of possible unfiled mechanics' liens.

The advantages enuring to subcontractors and materialmen outweigh the disadvantages to the owner. The rights of a bona fide mortgagee can be protected by provisions somewhat similar to the present $N$ ew Jersey law, ${ }^{22}$ or by the owner paying the balance of the contract price into court for distribution. ${ }^{23}$

\section{Statutes Making Misapplication of Funds a Crime}

It may also be contended that the provision making the misapplication of construction funds a crime, adequately protects subcontractors and materialmen. This is not the fact. Such legislation if carefully drawn is probably constitutional but experience has taught us that it is extremely difficult to get a conviction.

The result of attempts to enforce such a provision in New York ${ }^{24}$ is illustrative of this fact. In a number of cases where the New York statute was brought to the attention of the owner or contractor, prompt payment has followed. However, to date there has not been a single conviction under

${ }^{\infty}$ Rice v. Baxter, I $_{\mathfrak{j}} \mathrm{Pa}$. C. C. I98, 3 Pa. Dist. 827 (1894).

$=$ U. M. L. A. §2.

N. J. Laws I898, p. 538, § I5, N. J. Coxrp. Stat. (Igro) p. 3303, as amended by N. J. Laws 1930 , c. $212, \$ 8$.

m Mechanics' Lien Act of Igor, supra note 8, § 2.5, PA. STAT. Axs. (Purdon, 1930) title 49, § I3.5; U. . I. L. A. \$25.

"N. Y. CoNs. Laws, supra note $4, \S 36$. 
section 36 of the New York Mechanics' Lien Act, although in Westchester County an indictment of a builder was procured under section 889 of the New York Penal Law, which provides that a person who, with intent to defraud or to conceal any larceny or misappropriation of any money or property, alters the records pertaining to the business, makes a false entry in his books of accounts, or wilfully omits to make a true entry of any material particular, is guilty of forgery in the third degrce. The trial of this case was brought to a close by the builder pleading guilty. $\mathrm{He}$ was sentenced to serve one year in the county penitentiary and fined $\$ 500$.

In another unreported case a builder diverted funds and disappeared. Shortly thereafter he was indicted, apprehended and jailed pending trial. At the trial it developed that while he had given a building and loan mortgage he had received no advances thereon, but had received money from a third party. He had approached a money lender for a loan. The money lender stated he could arrange for the builder to borrow money from the bank on the builder's personal note which the lender would endorse. This was done and then the lender suggested a building and loan mortgage on the property. The indictment was quashed. ${ }^{25}$

There have been a number of other indictments in New York under section 36 of the Lien Law but the cases have not as yet gone to trial.

To appreciate section 8 of the proposed Uniform Mechanics' Law which deals with this subject it is helpful to review the existing legislation on the subject and the decisions thereunder.

In I887 the legislature of Minnesota sought to make the mere failure of a contractor who had received payment from the owner to pay laborers and materialmen, a felony. It was not necessary under this statute that the contractor be guilty of any fraud or any other wrong in order to subject him to the penalties of the statute. If a contractor had received his pay from the owner and owed a debt to a laborer or materialman which the contractor was unable to pay, the statute made the contractor guilty of obtaining money under false pretenses no matter how honest had been his intention to pay the laborer or materialman out of the money he had received on the contract. Of course, this statute was held unconstitutional because it attempted to impose imprisonment for non-payment of an existing debt. ${ }^{26}$

In I9I 5 the legislature in Minnesota passed a new acr which provided that any contractor or subcontractor within the meaning of the lien laws, who, with intent to defraud, should use the proceeds of any payment made

$\approx$ To meet this situation an amendment was considered (but not passed) by the New Fork Legislature in 1932 designed to enlarge upon the definition of a building loan mortgage, to read "The term shall include a mortgage pursuant to which the mortgagor agrees to advance funds to an owner on account of an improvement to be made by such owner, although there is no express agreement between such owner and the mortgagee to make such improvement."

Myer v. Berlandi, 39 Minn. 438, 40 N. W. 5 I3 (I888). 
to him on account of such improvement for any purpose other than the payment of labor, material or machinery contributed to such improvement while any such debts at the time of such payment remain unpaid, should be guilty of larceny.

This statute was held to be constitutional, ${ }^{2 \pi}$ the court pointing out, as have the courts in South Carolina, ${ }^{28}$ Washington ${ }^{29}$ and Wisconsin, ${ }^{30}$ that the purpose of the statute is not to imprison for debt, but to punish the fraud. The statute imposes the penalty not because of the debt nor for the purpose of collecting the same, but by reason of the expenditure with intent to defraud labor and materialmen.

Section 8 of the proposed Uniform Act provides that the payment must be "with intent of fraud" to constitute a crime.

While it would seem that such an intention is essential to make the act criminal, the effect of this clause is to give the offender an excellent opportunity to escape punishment. The burden of proving the intent to defraud rests upon the state. Not only is it difficult to find prosecuting officials who will devote to the case the time necessary to make a thorough study of the required details, but it is only in rare instances that a jury will convict after a prima facie case has been made out.

The legislation in Wisconsin does not contain the "intent to defraud" clause. However, when it was urged that the Wisconsin statute was uncon:stitutional because of the absence of the clause under consideration, the majority of the Supreme Court of Wisconsin held that since the statute declares certain specified acts to be embezzlement, the wrongful intent is necessarily implied and included in the statute, and, therefore, it is not essential to the validity of the statute that the intent be more specifically expressed. The majority opinion points out:

"Hence, a conviction under the statute cannot be had without proof beyond a reasonable doubt of an intent to defraud." 31

Likewise, the statutes in Kentucky, New York and South Carolina do not contain the express clause "with intent to defraud".

The Michigan statute of I93 I and the Virginia statute effective June 2 I, I932, ${ }^{32}$ each contains a clause, the substance of which should be added as a new sub-section to section 8 of the proposed Uniform Mechanics' Lien Law. This section of the Michigan statute is as follows :

"State v. Harris, 134 Minn. 35 , I58 N. W. 829 (1916). In Wooley v. Chopman, 175 Minn. I86, 220 N. W. 605 (I928), an action for malicious prosecution was instituted against the agent of a supply house who advised the owner to institute criminal proceedings under this act. The plaintiff had paid a sum sufficient to cover his debt on the job under consideration to the supply house. However, the supply house, contrary to plaintiff's directions, applied the payment to a former indebtedness. Judgment for plaintiff was affirmed.

$\approx$ State v. Hertzog, 92 S. C. I4, 75 S. E. 374 (I9I2).

$\approx$ State v. Williams, I33 Wash. I21, 233 Pac. 285 (I925).

so Pauly v. Keebler, I75 Wis. 428 , I85 N. W. 554 (I92 r).

si Ibid. at $436,185 \mathrm{~N}$. W. at 356 .

Nich. Pub. Acts I93I, p. 445; Va. Act of March 24, 1932. 
"The appropriation by a contractor or any sub-contractor of any moneys paid to him for building operations before the payment by hin of all moneys due or so to become due laborers, sub-contractors, materialmen. or others entitled to payment, shall be evidence of intent to defraud."

The report of the Committee on a Uniform Mechanics' Lien Act presented at Chicago in I930 contained the following paragraph, which has been eliminated in the I93I draft:

"The use by such owner of the proceeds mentioned in sub-section I of this section or the use by such architect, landscape architect, engineer, contractor, sub-contractors, or other person of the proceeds mentioned in sub-section 2 of this section for any purpose other than the payment of such unpaid amount shall be prima facie evidence of intent to defraud." 33

While this paragraph may seem objectionable to some contractors, an honest contractor need not fear its effect since he either pays his bills or is able satisfactorily to explain his failure or inability to do so. The difficulty in procuring a conviction of jerry-builders justifies the retention of the omitted paragraph since it shifts to some extent to the defendant the burden of proving that the failure to pay his labor and materialmen was done without intent to defraud them. It still remains the duty of the state to satisfy the jury, beyond a reasonable doubt, that the defendant is guilty of the crime with which he is charged. ${ }^{34}$

The Criminal Code of South Carolina provides:

". . Any contractor or contractors of subcontractors who shall. for other purposes than paying the money loaned upon said contract, expend and on that account fail to pay to any or all laborers. subcontractors and materialmen out of the money received," for the erection, alteration or repairs of buildings, "shall be deemed guilty" of a misdemeanor. ..." 35

This statute was held constitutional, ${ }^{36}$ although a dissenting Judge contended that the act was unconstitutional, holding as follows:

${ }^{33}$ Sixth Report of the Committee on Uniform Mechanics' Lien Act, $\$ 8$ (3). We understand that the Committee removed this section because there was considerable objection to the penal sections of the act which, it was thought, might occasionally work an injustice. As there is considerable sentiment in a number of states in favor of this clause, there is nothing to prevent a legislature which adopts the Uniform Mechanics' Lien Act from adding such a clause therein if it is deemed advisable to do so. However, a completely uniform law is desirable.

3. The law ir New York state was amended March 31, 1932, to require owners, contractors and subcontractors to keep books and making the failure to keep such books and records and/or the failure to furnish a statement showing disbursements in detail, presumptive evidence tliat such owner, contractor, subcontractor, has applied and/or consented to the application of trust funds for purposes other than those specified in the statute. Section 36 (d).

*S. C. CRIM. CODE (I922) § I73.

so State v. Ifertzog, supra note 28. 
"It is said that the true basis of criminality is that the law makes the contract price a trust fund, and when the contractor does not pay the lien debt he has committed a breach of trust. If that be granted, it still would not sustain the statute, because a breach of trust, to be criminal, must be with fraudulent intent. Neither fraud nor anything that imports fraud is contained in this statute." $3 \pi$

The statutes in South Carolina, ${ }^{38}$ New York $^{39}$ and Michigan ${ }^{40}$ expressly declare that the funds so received are trust funds. The Penal Code of California provides: ${ }^{41}$

"Any contractor who appropriates money paid to him for any use or purpose, other than that for which he received it, is guilty of embezzlement, and payment of laborers and materialmen for work performed or material furnished in the performance of any contract is hereby declared to be the use and purpose to which the contract price of such contract, or any part thereof, received by the contractor shal! be applied."

This act was declared unconstitutional. ${ }^{2}$ The court pointed out that the theory on which the state might attempt to justify the conviction is that the statute itself enters into and becomes a part of every building contract so that the provisions of the contract to the contrary notwithstanding, the absolute, unconditional title to money paid to the contractor under his contract does not pass to him, but is received by him in trust for certain uses. The court held :

"A statute that consummates such a result abridges the privileges of citizens of the United States and deprives them of property without due process of law." 43

It was also held that the police powers could not be made a cloak under which to overthrow or disregard constitutional rights. ${ }^{44}$

The same contention was raised in Wisconsin but was overruled by the court. This court held that even in the absence of an agreement, express or implied, there is at least a reasonable expectation on the part of the owner that the money will not be diverted to other uses, that when the contractor

3I Ibid. at 30,75 S. E. at 380 .

* Supra note 35 .

$\$ N$. Y. Laws 1930, I59I (private work); Amendment of I932, $\$ \$ 2.5$ (a) and 2.5 (b) (public improvements).

${ }^{*}$ Supra note 32.

"Cal. Pexal Code (Deering, 1923) § jo6.

¿ People v. Holder, 53 Cal. App. 45 (Ig2I). See also American Surety Co. of N. Y. v. Bank of Italy, 63 Cal. App. I49 (1923).

"People v. Holder, supra note 42 , at 5 I.

"The parties in interest again have some protection in California, since the Contractors' Registration Act, as amended by Cal. Laws I93I, c. 578, provides that diversion of funds or property received for prosecution or completion of a specific contract constitute ground for revocation of the contractor's license. 
receives the money from the owner he owes a duty to the third persons whose labor and materials have enabled him to obtain that money and there is, even without the aid of a statute, a confidence closely akin to a trust relationship and extending to both the owner and to those whose material or labor has entered into the structure that the compensation paid therefor by the owner shall not be misapplied. ${ }^{45}$

This constitutional question in connection with such legislation has not yet been passed upon by the Supreme Court of the United States.

The proposed Uniform Act does not expressly make the moneys received by the contractor from the owner or by the subcontractor from the contractor trust funds and thus the disputed point may have been avoided.

Washington has attempted to solve the problem by providing that every person who has entered into a contract to furnish labor or material for which a lien may lawfully be had, who shall receive payment therefor, or on account thereof, receives the same as the agent of the party with whom he contracted, for the purpose of paying all claims for labor and materials supplied, and that any such agent, who, with intent to deprive or defraud the owner thereof, shall withhold or appropriate the same to the use of any person other than the true owner or persons entitled thereto shall be guilty of larceny. ${ }^{46}$

The Supreme Court of Washington, in holding this act constitutional, ${ }^{47}$ diștinguishes the two systems of lien legisation, pointing out that, under one system, the contractor is the agent of the owner in procuring the completion of the building and that, as a consequence, in the states where this system is in force, the corollary statute making the agent criminally liable for misappropriation is valid, whereas, in states where an agency is not created by the statute, it follows that the criminal statute is unconstitutional. ${ }^{48}$

In Kentucky, ${ }^{49}$ the legislature has not overlooked the owner. The Act provides that, if an owner shall contract for labor and materials used in the erection or repair of a building under such circumstances that a lien for the payment for such labor and material may attach to the property, and shall sell or mortgage the premises before the expiration of the time provided by law for the filing and recording of a mechanic's lien claim, the owner shall, when he receives the consideration for such sale or the proceeds of such loan, pay debts of construction, unless released in writing by the person or persons furnishing the labor or material. If the fund is insufficient to permit payment in full to be made, the owner is required to pro-rate the money

¿ Pauly v. Keebler, supra: note 30.

W6 Wash. CoMp. Stat. (Remington, I922) $\$ 2604$.

- State v. Williams, supra note 29.

ts While the illustrations , given by the judge writing the opinion in this case do not affect his reasoning, the court gave as the illustration of the Pennsylvania system a situation which is properly applicable to the New York system, and vice versa.

${ }^{4} \mathrm{Kr}$. Stat. (Carroll, I930) $\$ 2467$. 
to the persons entitled thereto. A violation of this statute is made a misdemeanor.

Likewise, where any payments are made by the owner to the contractor, the contractor is required to pay all persons who have furnished labor and material from the proceeds so received to the extent that the proceeds are sufficient for that purpose, unless labor or materialmen shall have waived in writing their right to file a mechanic's lien claim. A violation of this law is also made a misdemeanor, subject to fine and imprisonment.

This statute came before the court for construction in a case where an owner mortgaged the property before the expiration of the time for filing liens and, having obtained the money, refused to pay the contractor therefrom. The conviction was set aside because the indictment failed to aver that the contractor had not perfected his lien prior to the time when the owner created the mortgage. A reading of the opinion by the Supreme Court of Kentucky would lead to the conclusion that, if the indictment had been in proper form, the conviction would have been sustained. ${ }^{50}$

These statutes have been criticized on the ground that they are class legislation which deny equal protection of the law to all citizens. It has been decided in South Carolina, ${ }^{51}$ Minnesota, ${ }^{52}$ Washington ${ }^{53}$ and Wiscon$\sin ^{54}$ that the classification made by the legislature is not unreasonable. The statute does not select any class of persons for special consideration, but declares that certain acts, done by certain persons under certain circumstances, and with a fraudulent intent, shall constitute a crime. This constitutional question is also one upon which the Supreme Court of the United States has not passed in connection with statutes such as we are considering.

\section{Responsibility of Owner or Mortgagor for Construction Funds}

The Uniform Act is superior to most of the existing statutes in that it seeks to fix responsibility on the owner, as well as on the contractor and subcontractors. ${ }^{55}$

The lien law of New York, as amended in $1930,{ }^{56}$ provides that the fund received by an owner under any payment or advances made pursuant

${ }^{\omega}$ Wolking v. Commonwealth, $236 \mathrm{Ky} .74 \mathrm{I}, 33 \mathrm{~S}$. W. (2d) 647 (1930). However, in State v. Williams, I4I Wash. $148,25 \mathrm{I} \mathrm{Pac}$. II5 (1926), it was decided that, in a prosecution for embezzlement by an agent of a sum entrusted to her to supply labor and material on a building, it was not necessary to prove that a mechanic's claim was filed for services rendered by a laborer, but it was only necessary to show that services had been rendered for which a mechanic's claim could be filed.

st State v. Hertzog, supra note 28.

c State v. Harris, supra note 27 .

- State v. Williams, supra note 29.

s Pauly v. Keebler, supra note 30 .

$\approx$ U. II. L. A. \$ 8 .

c Supra note $4, \$ 36$. These provisions were extended to conveyances by section 13 (5) Amendment of I032, effective July $\mathrm{I}$, 1932. This amendment provides that an instrument of conveyance recorded subsequent to the commencement of the improvement, and before the expiration of four months after the completion thereof, shall not be valid as against 
to a building loan contract and secured by a building loan mortgage and the fund received by an owner under every mortgage containing the covenant by the mortgagor that he will receive the advances secured thereby as a trust fund to be applied for the purpose of paying the cost of improvement and that he will apply the same first to the payment of the cost of improvement before using any part of the total of the same for any other purpose, are declared to constitute trust funds in the hands of the owner to be applied first for the purpose of paying the "cost of improvement", which term is defined by the act. ${ }^{57}$

In New Jersey, ${ }^{5 \&}$ a mortgagee is entitled to priority over mechanics' lien creditors where the funds secured by the mortgage have been applied, among other things, to the payment of premiums, counsel fees, and other financing charges, the total of which is not in excess of five per cent. of the principal of the mortgage.

The language of subdivision I of section 8 of the proposed Uniform Act defines "net proceeds" to be the amount remaining after deducting from the face value of the loan:

"(a) the amount of the fees and charges legally and necessarily incident to the procuring of the loan;

"(b) the amount required to satisfy prior encumbrances against the real property and the fees and charges legally and necessarily incident thereto, if such encumbrances are paid or to be paid with the consent of the lender, from the proceeds of the loan; and

"(c) the amount of fees and charges for professional services

- for which liens are not prorided by this act and which are bona fide - rendered in connection with the improring of the real property."

This is far better than fixing an arbitrary percentage.

liens filed during the said period, unless the instrument contains a covenant by the grantor that he will receive the consideration as a trust fund to be applied first to the payment of the cost of the improvement and that he will apply the same first to the payment of the cost of the improvement before using any part of the total of the same for any purpose.

: "The expenditures incurred by the owner in paying the claims of a contractor, an architect, engineer or surveyor, a subcontractor, laborers and materialmen arising out of the improvement, and shall also include fair and reasonable sums paid for obtaining building loan and subsequent financing, premiums on bond or bonds" (to discharge liens) "required by any such building loan contract or by any lease to be mortgaged pursuant thereto, or required by any mortgage to be subordinated to the building loan mortgage, sums paid tc take by assigrment prior existing mortgages, which are consolidated with building loan uortgages and a!so the interest charges on such mortgages, sums paid to discharge or reduce the indebtedness tinder mortgages and other incumbrances upon real estate existing prior to the time when the" (mechanic's lien) "may attach, sums paid to discharge building loan mortgages whenever recorded, taxes, assessments and water rents existing prior to the commencement of the improvement, and also those accruing during the making of the improvement, and interest on building loan mortgages, ground rent and premiums on insurance likewise accruing during the making of the improvement. The application of the proceeds of any building loan mortgage or other mortgage to reimburse the owner for any payments for any of the above mentioned items for said improvements prior to the date of the initial advance received under the building loan mortgage ... . [is] deemed to be an expenditure within the 'cost of improvement' as above defined; provided, however, such payments are itemized in the luilding contract and/or mortgage other than a building loan mortgage, and provided further, that the payment has been made subsequent to the commencement of the improvement." X. Y. Lien Law, $\$ 2$, as amended in 1932, effective July I, I932.

is Supra note 22. 


\section{Attaching Date of Liens}

In Pennsylvania, a mechanic's claim for repairs is a lien from the date of filing (unless the property has been conveyed in good faith prior to the date on which the claim was filed) but a claim for new work takes effect as a lien from the date of the visible commencement, upon the ground, of the work of construction. ${ }^{59}$

Several cases have arisen in Pennsylvania where a mortgage was threatened with divestiture by reason of work performed upon the ground, such as removing a fence and shrubbery, constructing a temporary driveway, etc., but where the mortgage was recorded before the actual commencement of the building operation. ${ }^{60}$ For this reason, it is submitted that the provisions of the proposed Uniform Act, to the effect that all liens shall relate to and take effect from the time of the visible commencement of operations, except that where demolition is involved in the work of improving, liens, other than for demolition, shall relate to and take effect from the visible commencement of operations (excluding demolition and delivery of materials for such demolition) ${ }^{61}$ are superior insofar as new work is concerned, even though some difficult problems dealing with divestiture of mortgage liens may arise where demolition is commenced before the mortgage is recorded.

Whether or not the Pennsylvania statute, which provides that claim for alterations takes effect as a lien from the date of filing, is an improvement over the provisions of the proposed Uniform Act is a subject of relatively minor importance, although it would seem that a mortgagee is entitled to the protection afforded by the Pennsylvania statute.

Neither the Pennsylvania law nor the proposed Uniform Act require the net proceeds of such mortgages to be used to pay any of the debts of construction, except that the Uniform Act provides that, if the owner borrows money on a mortgage, representing that the proceeds shall be used for construction purposes, and then with intent to defraud fails to do so. he is guilty of a crime. ${ }^{62}$

In New York, ${ }^{63}$ a building loan mortgage, to achieve priority over liens subsequently filed, must contain the clause that the mortgagor will treat the moneys received by him as trust funds and apply the same to pay the cost of the improvement. This statute also provides that the building loan contract must be in writing and must contain a tiue statement under oath, verified by the borrower, showing the consideration paid, or to be paid, for

${ }^{\circ}$ Mechanics' Lien Act of Igor, supra note $8, \$ \$$ ro, I3.

${ }^{\infty}$ Reading v. Hopson, $90 \mathrm{~Pa}$. 494 (I879) ; Ketcham v. Land Title, $257 \mathrm{~Pa}$. 391, Ior At1. 764 (1917); Kanoisky v. Carey, 89 Pa. Super. 422 (1926); Knoell v. Carey, $285 \mathrm{~Pa} .498,501$, 132 Atl. 702 ( 1926 ).

${ }^{2}$ U. M. L. A. \$ 3.

$\approx$ U. M. L. A. \& 8 .

- Supra note 4. For conveyances see Amendment of 1932, \$ I3 (5). 
the loan and all other expenses, if any, incurred or to be incurred in connection therewith, and the net sum available to the borrower for the improvement, and must be filed as a public record. If not so filed, the interest of each party to such contract in the real property affected thereby is subject to the lien and claim of a person who shall thereafter file a notice of lien. Thus a materialman has the means of ascertaining what part of the proceeds of a mortgage loan will be, or, at least, should be available for debts of construction. If an exorbitant bonus is charged, that fact appears.

In New Jersey, a mortgage has priority over subsequent lien creditors, provided the funds secured thereby shall secure or have been applied to certain specified payments. ${ }^{64}$

Subsection 2 of section 8 of the proposed Uniform Act provides that an owner who procures a loan secured by a mortgage or other encumbrance on certain real estate, who represents, either to the mortgagee or to one or more prospective lien claimants, that the proceeds thereof are to be used for the purpose of improving real estate and who, with intent to defraud, uses such net proceeds or any part thereof for any purpose other than to pay for labor, services or material furnished for the specific improvement, while any amount for which such owner may become liable for such labor, services or material remains unpaid or while any amount of which he has received notice of non-payment remains unpaid, shall be guilty of a crime.

This provision makes it necessary for a claimant to search the record. If he finds encumbrances of record which seem to him to be out of proportion to the value of the land and the cost of the proposed structure, he must refrain from extending credit, and, if he extends credit, he must anticipate that the mortgagee will have priority in distribution for all advances made by the mortgagee, irrespective of how the fund is disbursed by the owner, unless the owner has made the representations above reviewed and, with intent to defraud, fails to carry out his obligation. Such a provision simplifies the responsibility of a lending institution and, if this provision be retained in the proposed Uniform Act, it is suggested that section 26 be

os To the payment:

I. of all or part of the purchase price of the lands covered thereby;

2. of any valid lien or encumbrance which would be prior to any mechanic's lien claim;

3. of any tax assessment or other municipal lien or charge due or payable at the time of such payment;

4. of any premium, counsel fees, and/or other financing charges, the total of which shail not exceed five per cent. of the principal of the mortgage securing the loan upon which it is based;

5. to every one who shall have furnished labor or material for said building and who shall have filed the proper notice of intention, unless such claimants have released or postponed their rights or failed to comply with other conditions imposed by the statute;

6 . to the owner or the mortgagor of such moners as he may have actually expended for labor or material used in the construction or repair of the building upon the lands covered by the mortgage after payment has been made in full to all other persons entitled to participation in the proceeds of the mortgage;

7. to mortgagor or owner of any balance of any advance made on account of any mortgage after the substantial completion of the building and the payment or barring of mechanic's lien claimants. N. J. Laws I930, c. $212, \S 8$. 
amended to permit a prospective lien claimant to make inquiry of the lender whether the borrower had made any representations to the lender concerning the use to be made of the fund secured by the mortgage and to give the mechanic's lien creditor priority over the mortgage to the extent of his lien claim, if the lender fails to answer the inquiry within a reasonable time or gives a wilfully false answer. ${ }^{65}$

In view of the abuses which were common in New York, prior to I930, it would seem that the provisions of the New York act above referred to, requiring the building loan contract to be recorded, do not work an undue hardship and would simplify matters, because the various prospective subcontractors and materialmen could inspect the public records and would not need to make inquiry from the mortgagee.

\section{The Uniform Act Compared With the Pennsylvania System}

The proposed Uniform Act confers the right of lien on materialmen and subcontractors and grants novel preferences to laborers. ${ }^{66}$ These provisions either have been or undoubtedly would be held unconstitutional in Pennsylvania. ${ }^{6 \tau}$

The proposed Uniform Act defines the word "improvement" to mean, among other things, "grading, seeding, sodding or planting for landscape purposes". ${ }^{6 s}$ A mechanic's lien may not be maintained for such labor and material in Pennsylvania. ${ }^{60}$

Under the proposed Uniform Act a lien may be had for the removal of a structure. $^{70}$ The law in Pennsylvania is to the contrary, section 38 of the Act of June 4, Igor, P. L. 43I, having been declared unconstitutional. ${ }^{i 1}$

Under the proposed Uniform Act an architect may have a lien merely for the preparation of plans. ${ }^{2}$ The Pennsylvania law permits an architect to maintain a lien as a contractor only if, in addition to the preparation of the plans and specifications, he superintends the construction of the improvement. ${ }^{73}$

*OHIO Gex. CoDE (Throckmorton, I926) \$ 8321-I.

$U$. M. L. A. $\$ \$ \mathrm{I}, \mathrm{5}$, and $2 \mathrm{r}$.

\% Favo v. Melot, $94 \mathrm{~Pa}$. Super. 508 (I928); see Allentown Nat. Bank v. Helios Chem. Co., 9 Pa. Super. $275,282(1899)$.

G U. M. L. A. \$ I.

${ }^{\infty}$ Parkhill v. Hendricks, $53 \mathrm{~Pa}$. Super. 9 (Igr3).

$\rightarrow$ U. M. L. A. $\$ \S \mathrm{I}$ and $\mathrm{I2}$.

7 Henry Taylor Lumber Co. v. Carnegie Institule, 225 Pa. 486, 74 Atl. 357 (1909).

T. M. L. A. \& 2.

3 Dyer v. Wallace, 264 Pa. I69, I07 Atl. 754 (I9I9) ; Hoekstra v. Hopkins, $87 \mathrm{~Pa}$. Super. I5 (19=6). But see, Silfres v. Austin, Pa. Super., Oct. Term, 193I, No. 3\&2, where it is held that the real test is whether or not the work performed by the architect was part of the services rendered in connection with the erection and construction of the building and enlancing the value thereof. Here the lien set forth that the character of the services furnished was, among other things, the inspection and visiting of the site from time to time and the issuance of the necessary certificates. It was held that such services were rendered in connection with the erection of the building as contemplated by the statute and that the architect was entitled to maintain a mechanic's lien claim for the contract price. 
In Pennsylvania, ${ }^{74}$ as well as under the proposed Uniform Mechanics' Lien Act, ${ }^{i 5}$ where the amount demanded is for labor performed or materials furnished for more than one improvement to be operated as a single plant although located on separate lots, a lienor is required to file only one mechanic's claim covering his entire demand. If, however, the several structures are not intended to form parts of a single plant, giving that word its ordinary commercial meaning as property owned or used in carrying on some trade or business, a separate mechanic's claim must be filed against each building on the basis of an apportionment of what is due the claimant.

In Pennsylvania, a mechanic's lien claim is fatally defective unless within one month after the mechanic's claim has been filed. the claimant, whether he be a contractor or subcontractor, serves upon the owner a notice of filing of the mechanic's lien claim and files of record in the proceedings an affidarit setting forth the fact and manner of such service. ${ }^{76}$ Under the proposed Uniform Act "i actual service of copies of the claims or lien, amendments thereof and of assignments thereof is required to be made within ten days after the instrument is filed. If within such ten days such service is found to be impractical, substituted service may be had during the following twenty days. However, a failure by any lienor to so serve a copy of his lien or claim, or any amendment thereto, renders his claim voidable only to the extent that such failure is shown to be prejudicial to the owner. ${ }^{78}$ - The proposed Uniform Act also provides for payments to lienors by the owner when the owner has been served with notice of their claims. ${ }^{79}$ These provisions define what constitutes proper payment by the owner and are very desirable in the states where the New York system is in effect. If an owner fails to retain such a portion of a contract price as will be sufficient to pay all amounts due or to become due laborers (including those thereafter employed) for all labor or services performed by such laborers, the owner may subject himself to the liability of additional payment. An owner should be in a better position to suffer the loss than would laborers and it is assumed that the amount of such unpaid labor bills will never be substantial.

"Mechanics' Lien Act of Igor, supra note 8, \& I2; Sumption v. Rogers, 242 Pa. 348, 89 Atl. I2I (I913); Todd v. Gernert, 223 Pa. 103, 72 Atl. 249 (I909).

$\approx$ U. M. L. A. §I6.

"Mechanics' Lien Act of IgoI, supra note $8, \S 21$, as amended by the Act of April 5, 1917, P. L. 42, PA. Stat. ANx. (Purdon, 1930) title 49, $\$ 131$; O'Kane v. Murray, 252 Pa. 60, 97 Atl. 94 (I916).

"U. M. L. A. § I9.

U. M. L. A. § 20 .

The owner may make these payments directly to laborers as their claims are presented. Sums in addition to the amounts necessary to pay the claims of laborers may be paid directly to other lienors, the owner being required to recognize only the claims concerning which he has received notice up to the time of payment. Before making payment to lienors, the owner must give the contractor ten days' written notice of his intention so to do. U. M. L. A. $\$ 5$. 
Before paying any money directly to a laborer or lienor, the owner must give the contractor at least.ten days' written notice of his intention to make such payment. ${ }^{80}$ In Pennsylvania after an owner has been served with a notice of intention to file a lien, the owner may, unless approved security be given to indemnify him against loss, retain out of any fund due or to become due the contractor a sum sufficient to protect him from loss. ${ }^{\text {s1 }}$ The owner served with proper notice of intention to file a mechanic's lien claim may serve a copy thereof upon the party personally liable for the debt therein referred to with notice that unless such claim is satisfied within fifteen days thereafter, or the owner is furnished with a sworn statement setting forth therein its intention to be disputed, the owner may pay the same and deduct the amount thereof from the contract price or hold the contractor personally liable for any loss. ${ }^{32}$

Where a husband with the knowledge of his wife contracts in his own name for the construction of a dwelling, in Pennsylvania, on land belonging to the wife or owned by the husband and wife as tenants by the entireties, the lot and building is subject to lien for work done and materials furnished. $^{\mathrm{s3}}$ By section $\mathrm{I} 3$ of the proposed Uniform Act when the contract for improving real property is made with a husband or wife who is not separate and living apart from his or her spouse and the property is owned by the other, or both, the husband or wife who contracts is deemed to be the agent of the other spouse, unless the other shall within ten days after learning of such contract give the contractor written notice of his or her objection thereto.

It has been held in Pennsylvania, since the lien of a claim attaches to the building primarily and to the land only incidentally, that if the building is destroyed by fire or other casualty the right of lien is lost. ${ }^{54}$ The rights of the parties with reference to insurance is set forth in section 49 of the Pennsylvania Mechanics' Lien Act of Igor. ${ }^{85}$ The proposed Uniform Act provides that the proceeds of any insurance policy received or to be received after a fire loss shall, after reimbursement has been made for premiums paid, be subject to the liens to the same extent and in the same order of priority as the real property would have been had such improvement not been damaged, destroyed or removed. The named assured to whom payment is made is deemed a trustee of such proceeds for the purpose designated by the proposed statute. ${ }^{s 6}$

${ }^{80}$ U. MI. L. A. \$ 5 (5).

82 Mechanics' Lien Act of Igor, supra note $8, \S 8$, as amended by the Act of March 24, 1029, P. L. 65, PA. STat. A.rs. (Purdon, 1930) title 49, § IOr.

Ibid. $\$ 9$.

$\approx$ Ibid. $\$$ t. Disopra v. Curtis, 40 Montg. 209 (Pa. I924), 4 I Montg. I46 (Pa. 1925).

s Wigton and Brooks' Appeal, $28 \mathrm{~Pa}$. I6: (1857); Linden Steel Co. v. Rough Run Mífg. Co., I5B Pa. 238, 245, 27 Atl. 895 (1893).

¿ Clark v. Heller, Pa. Super., Oct. Term, I93r, No. 223.

s3. II. L. A. § I4. 
In Pennsylvania a mechanic's lien claimant may proceed simultaneously upon his claim and by a separate personal action against the party with whom he contracted. ${ }^{87}$ The proposed Uniform Act provides that if a lienor shall fail for any reason to establish a lien for the full amount found to be due him in an action under the statute, he may in addition to the lien decreed in his favor recover a judgment or decree in such action for sums in excess of the lien which he might recover in an action on a contract against any party to the action from whom such sums are due him. A judgment or decree may be awarded in favor of any party. ${ }^{88}$ Such a procedure has been declared unconstitutional in Pennsylvania. ${ }^{\text {so }}$

Section II of the proposed Uniform Mechanics' Lien Act recently adopted in New York ${ }^{90}$ permits a person who has delivered materials for the improvement, which have not been incorporated therein and for which he has not received payments, to repossess and remove such materials. Section 38 of the Pennsylvania Mechanics' Lien Act of IgoI, seeking to confer the right to remove the improvement from the land, has been declared unconstitutional. $^{91}$ It is.reasonable to assume that legislation conferring the right to repossess materials not used, title to which has passed from the materialman, would likewise be held unconstitutional in Pennsylvania. Of course, if the subcontractor or materialman has retained title to his material, where his contract is not merely to furnish material, but is to furnish and to forthwith erect the same, he is not without a remedy, especially if the materials are still in their original packages. ${ }^{92}$

In Pennsylvania, a claimant is required to issue a writ of scire facias upon his mechanics' claim within two years after the date on which the mechanics' lien claim was filed unless the owner waives the necessity for so doing in the manner and within the time prescribed by the Act of Assembly. A verdict must be recovered or judgment entered on the scire facias within five years after it is issued. Final judgment must be entered on the verdict within five years after its recovery. ${ }^{93}$ No lien provided by the proposed Uniform Act, shall continue for a longer period than one year after the

8: Ott v. DuPlan Silk Corp., 27I Pa. 322, II4 At1. 630 (I93I). However, in the action upon the mechanic's claim, recovery is limited to the value of the work actually done and the materials actually furnished, and the profit which follows as a consequence of the performance of this work. A mechanic's claim cannot be maintained for unliquidated damages for breach of contract. Deeds v. Imperial Brick Co., 219 Pa. 579, 69 Atl. 78 (I90S).

${ }^{\circledR}$ U. M. L. A. $\S 30$.

sterling Pronze Co. v. Syrrie Imp. Ass'n, 226 Pa. 475, 75 Atl. 668 (1910).

${ }^{\infty}$ Amendment of 1932 , being section $39-\mathrm{c}$ of the New York Law.

${ }^{91}$ Henry Taylor Lumber Co. v. Carnegie Institute, supra note 7 I.

Commonwealth v. McFarland-Meade Co., $86 \mathrm{~Pa}$. Super. 67 (1926); Indiana Limestone Co. $2 t$ al. v. Nelson-Pedley Const. Co., is Pa. D. \& C. 562 (1931); Ball Engineering Co. v. White, 250 U. S. 46, 39 Sup.' Ct. 393 (I919); Calhoun County v. American Constr. Co., I52 Ala. 607,44 So. 876 (I907).

${ }^{\infty}$ Mechanics' Lien Act of I90I, stipra note 8, \& 10; Hiestand v. Keath, 229 Pa. 149, $7 \varepsilon$ Atl. 40 (I9I0); Sterling Bronze Co. v. Syrie Imp. Ass'n, supra note 89. 
claim of lien has been filed, unless within that time action to enforce the lien is commenced. ${ }^{94}$

In Pennsylvania, as a condition precedent to payment for labor or materials, the party making the same may demand from the person entitled thereto, a receipt stating the amount thereof and for what it is given. ${ }^{95}$ However, in the absence of an express appropriation by the debtor, or such a request by the person making the payment, elementary principles apply. ${ }^{96}$ Section to of the proposed statute provides that when a payment for materials is made to a subcontractor or materialman, such subcontractor or materialman shall demand of the person making such payments a designation of the account and the items of account to which such payment is to apply. In any case where a claim of lien for materials furnished is made by a subcontractor or materialman, it shall be a defense to such claim to prove that a payment made by the owner to the contractor for such materials has been paid over to such subcontractor or materialman and to prove also that when such payment was received by such subcontractor or materialman he did not demand a designation of the account or items of account to which such payment was to be applied or, receiving such designation, failed to apply such payment in accordance therewith. ${ }^{97}$

Thus, it will be seen that while some of the provisions of the proposed Uniform Mechanics' Lien Act are superior to the present Pennsylvania law, others are not. Many provisions of the proposed statute are inapplicable to Pennsylvania for the reason that the changes suggested have been, or undoubtedly would be held to violate section 7 of article III, of the Pennsylvania Constitution of 1874 , and thus the effect of an express repeal of the existing Pennsylvania Mechanics' Lien Act and the adoption of the proposed Uniform Mechanics' Lien Act would, to a great degree, deprive mechanics' lien claimants of the right to file and maintain a mechanic's lien claim in Pennsylvania.

\section{Conclusion}

It has been urged that the proposed Uniform Mechanics' Lien Act should be supported because it represents a compromise between the conflicting views of owners, contractors, subcontractors, materialmen, laborers and the lending institutions. Insofar as subcontractors and materialmen are concerned, the proposed Uniform Mechanics' Lien Act is as much a compromise as was the transaction at Yorktown between General O'Hara, the nominee of Cornwallis, and General Lincoln, on behalf of George Washington.

" U. M. L. A. §22.

Di Mechanics' Lien Act of Igor, supra note $8, \S 57$.

${ }^{\infty}$ Harker v. Conrad, I2 S. \& R. 30 I ( $\mathrm{Pa}$. I825) ; MrcKelvey v. Jarvis, 87 Pa. $4 \mathrm{I} 4$ (1878); Steinbach v. Keystone Auto Service Co., I6 Berks 66 (Pa. I923).

s. U. M. L. A. § Io (2). 
The British officers were permitted to keep their swords, but Great Britain lost a nation. So here, subcontractors and materialmen are given the abstract right to file and maintain a mechanics' lien claim, but this right is conferred only under such an impractical restriction as to force subcontractors and materialmen to forego the advantage of the proposed statute. A subcontractor will not antagonize the average contractor by giving notice before the subcontractor's bill is due and payable. If a responsible subcontractor or materialman knew, at the time he accepted an order, that it would be necessary to file a lien or to institute suit in order to obtain payment, he would refuse to extend the credit. Therefore, since the subcontractor and materialman assume that they will be paid for their labor or material, the result of the proposed Uniform Mechanics' Lien Act, unless the period within which notice must be given is extended, will be to repeal by indirection existing mechanics' lien legislation. The argument that credit practices in the industry will be improved by requiring such an untimely notice is fallacious.

The draftsmanship of the proposed Uniform Act is of the highest order. The need for uniformity is so great that this principal objective should always be borne in mind. Nevertheless, a statute to endure must be fair to all parties concerned. 